\title{
The Relevance of Judicial Procedure for Economic Growth
}

\author{
BERND HAYO \\ STEFAN VOIGT \\ CESIFO WORKING PAPER NO. 2514 \\ CAtegory 2: Public ChOICE \\ DECEMBER 2008

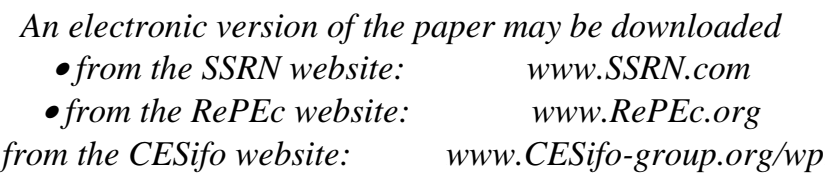




\title{
The Relevance of Judicial Procedure for Economic Growth
}

\begin{abstract}
It has been argued that procedural formalism undermines economic efficiency by fostering rent-seeking and corruption. We challenge this view by arguing that a number of judicial procedures foster economic growth by increasing the predictability of court decisions, which leads to more transactions and higher investment levels. We investigate the effects on economic growth of 15 judicial procedures. Employing a standard growth model, we find in a cross-section of 67 countries that timeliness, written - as opposed to oral-procedures, and the right to counsel have a positive effect on growth, whereas the number of independent procedural actions as well as the presumption of innocence have negative effects. Our results partially contradict the results of former studies based on the Lex Mundi dataset.
\end{abstract}

JEL Code: H11, K40, O40, P51.

Keywords: judicial procedure, legal formalism, judicial independence, rule of law, investment, growth.

\author{
Bernd Hayo \\ Philipps-University Marburg \\ Faculty of Economics and Business \\ Administration (FB 02) \\ Universitaetsstrasse 24 \\ 35307 Marburg \\ Germany \\ hayo@wiwi.uni-marburg.de
}

\author{
Stefan Voigt \\ Philipps-University Marburg \\ Faculty of Economics and Business \\ Administration (FB 02) \\ Barfüßertor 2 \\ 35302 Marburg \\ Germany \\ voigt@wiwi.uni-marburg.de
}

December 19, 2008

The authors thank Anne van Aaken, Matthias Dauner, Nora El Bialy, Aleksandra Gauss, Peter Nannestad, Sang Min Park, and Katharina Stepping for helpful comments. Previous versions of the paper were presented at the annual meetings of the American Economic Association (Chicago 2007), the European Association of Law and Economics (Copenhagen 2007), the Money, Macro, and Finance Group (Birmingham 2007), the Workshop on Measuring Law \& Institutions (Paris 2007), the European Public Choice meeting (Jena 2008), and at research seminars at the Universities of Brussels and Gießen. 


\section{The Relevance of Judicial Procedure for Economic Growth}

\section{Introduction}

The relationship between a country's legal system and its economic performance is still not completely understood. Some facets of the relationship are fairly obvious, of course. For example, flourishing economies crucially depend on secure private property rights and a functioning court system. It could even be argued that property rights are never secure in the absence of a well-functioning court system. The importance of courts being independent from the other branches of government, as well as from the conflicting parties, is often stressed, and yet judicial independence can also pose a danger. Judges acting without constraint or oversight may delay their decisions, issue decisions that ignore the evidence, render decisions that rely on nonapplicable norms, or even render decisions that are patently wrong. Independent judges could be viewed as a necessary condition for an efficient economy, but it is unlikely to be a sufficient one. An independent judiciary can constitute another type of danger, one precisely described by Brutus in the Anti-Federalist Paper \#11 (Ketchum 1986):

It is, moreover, of great importance, to examine with care the nature and extent of the judicial power, because those who are to be vested with it, are to be placed in a situation altogether unprecedented in a free country. They are to be rendered totally independent, both of the people and the legislature ... No errors they may commit can be corrected by any power above them ... nor can they be removed from office for making ever so many erroneous adjudications.

In more current language, one could say that judges ought to be held accountable to the law. One way to increase the chances that judges will make decisions rooted in the law is to use certain predefined rules that restrict judges in their decision-making power. These restricting rules are known as judicial procedures and have been implemented in various ways across all legal systems. We define "judicial procedure" as those formal steps that judges — and other actors involved in the judicial system — need to follow in order to produce binding decisions. In the United States this is called "due process."

The immediate purpose of the tools used to implement judicial procedure is to ensure that court proceedings are fair or, in other words, that procedural justice is maintained. If effectively enforced, their effect is to make it more difficult for judges to act outside the law. For instance, the right to legal counsel reduces the asymmetry in judicial expertise between the judge and the defendant by providing defendants with legal expertise. Lawyers can be expected to insist on the proper application of the relevant norms, which increases judges' accountability to the law. The right to appeal has a very similar function: Except at the highest level of court where it does not apply, the right to appeal creates awareness in judges that their decisions are not final, but can be reviewed for correctness by colleagues with higher status. 
This possibility creates an incentive to apply the relevant norms properly, and hence increases accountability. Similar arguments can be made with regard to all the other judicial procedures discussed in in the empirical section of this paper.

Thus, more accountability decreases the likelihood that judges will act arbitrarily and increases the predictability of the legal system. It can further be argued that procedural safeguards increase the likelihood that judges maintain their independence from other branches of government as well as from the conflicting parties. That is, if the parties (be they governmental or private) try to induce judges to draw on nonapplicable norms, judges know that such decisions are likely to be overturned by their colleagues (as a consequence of the right to appeal) or heavily criticized in public (as a consequence of the trial taking place publicly). Hence, judicial independence and judicial accountability are complementary.

Given this important role of judicial procedures, it is somewhat surprising how little empirical research has been done into the question of how these rules affect economic outcomes. We begin to fill in this gap by asking: What is the impact of important judicial procedures, such as the right to counsel, the right to present a defense, the presumption of innocence, or the right to appeal, on the average growth rate of an economy? We study the impact of judicial procedures using a unique dataset for a cross-section of 67 countries over the period 1985-2003 in the framework of a standard economic growth model. We find some support for our theoretical prior, as some judicial procedures appear to have a robust and statistically significant as well as economically relevant effect on economic growth. Our core findings are that timeliness, written (as opposed to oral) procedures, and the right to counsel have a robust positive effect on growth, whereas the number of independent procedural actions as well as the presumption of innocence have negative effects on growth.

The rest of the paper is structured as follows. Section 2 elaborates the main arguments relating the quality of the judicial process to economic growth and provides an overview of relevant extant empirical studies. Section 3 describes the dataset used in the analysis. Section 4 presents the empirical approach and a discussion of the results. Section 5 investigates different interpretations of the finding that the presumption of innocence has a negative impact on economic growth. Section 6 concludes.

\section{Competing Views on the Effects of Judicial Procedure}

One of the most basic problems of states is how to turn simple promises into credible commitments. If the state's promise to create and enforce private property is perceived as cheap talk by potential investors, trade and investment activity will be low. If, on the other hand, the 
promise to enforce private property rights is perceived as a credible commitment, trade and investment are likely to increase, leading to higher economic growth. There are at least three ways a state's policy toward private property can increase economic growth:

1. Regarding private law, the state's promise to enforce privately entered contracts is backed up by the presence of judicial procedures. This will increase the number of voluntary contracts and thereby the number of transactions. Moreover, it could increase people's willingness to specialize, which, in turn, would result in higher levels of division of labor, thus contributing to economic growth.

2. Using public law, the state credibly commits to a position of noninterference with private business outside the stated rules, which leads to higher foreign and domestic investment.

3. When the state issues bonds, it is able to do so at a low interest rate because it has credibly signaled the financial markets that it will avoid default and abstain from policy-induced inflation hikes. Lower interest rates on a given level of debt imply a lower intertemporal tax burden for the society, making it a more inviting business climate.

There are only a few studies concerned with the economic effects of judicial procedures. Feld and Voigt $(2003,2006)$ introduce two indicators of judicial independence (JI), one for de jure independence, the other for de facto independence. Estimating the impact of JI on economic growth, they find that while de jure JI does not have an impact on economic growth, de facto JI positively influences real GDP per capita growth in a sample of 73 countries. The impact of de facto JI on economic growth is robust to outliers, to the inclusion of several additional economic, legal, and political control variables, and to the construction of the index. The authors thus conclude that de facto JI matters for economic growth. Hayo and Voigt (2007) analyze determinants of de facto JI and the relationship between de jure and de facto JI. They show that the correlation between these two indicators for JI is quite low.

Djankov et al. (2003) develop an entirely different approach toward judicial procedure, which they call procedural or legal formalism. They describe a simple triadic model in which a dispute among neighbors is solved informally by a neutral third party (their neighborhood model). Such dispute settlement between neighbors works in the absence of formalized procedures and is used as a benchmark against which real-world systems are compared. Djankov et al. suspect that more formalized procedures do not serve to protect the conflicting parties but, rather, to secure government influence on court decisions. From this point of view, procedural tools would not contribute to higher levels of accountability and independence but are instead features of regulatory intervention creating unnecessary and costly burdens for the conflicting parties. Djankov et al. construct measures that reflect the exact procedures that are 
used in two paradigmatic cases (the eviction of a tenant for nonpayment of rent and the collection of a bounced check). Their index of procedural formalism measures "substantive and procedural statutory intervention in judicial cases at lower-level civil trial courts" and created by adding up the following variables.

(i) Professionals vs. laymen. Djankov et al. assume that by demanding conflicting parties to have professionally trained representatives and to accept only professionally trained people as judges, government increases its control over the judicial process. In our view, access to qualified experts increases the quality of judicial decision making.

(ii) Written vs. oral elements. Here, a critical argument (not explicitly developed by Djankov et al.) could be that requiring of all steps to be in writing could increase the incentives for corruption. If the only evidence allowed is that carrying the court's seal, parties might be willing to pay for the seal in certain situations, for example, when evidence is brought in too late. The counterargument (explicitly made in Djankov et al.) is that written litigation raises accountability as the entire procedure can be reproduced later.

(iii) Legal justification. Demanding legal justification would be yet another instrument of the sovereign to pursue its interests. We argue that it increases the relevance of legislation as the relevant laws need to be explicitly mentioned.

(iv) Statutory regulation of evidence. The regulation of evidence could, again, be used to further goals of the government. However, it could also enhance transparency of the process.

(v) Comprehensive appeal procedures. Djankov et al. suspect that a review of first instance court decisions by appellate courts does not serve to protect the conflicting parties from mistakes committed by first-instance judges but, rather, keeps the sovereign in control of court outcomes. Having a superior judge in control of lower court decisions is coded as inconsistent with the neighborhood model. In contrast, we think that such a procedure will improve the transparency of legal decision making.

(vi) Engagement formalities. Here, the argument is that voluntary pretrial conciliation is in accordance with the neighborhood model as are flexible rules of notification both of process and judgment. The competing view is that clearly defined engagement procedures will foster a fair trial.

(vii) Independent procedural actions. These are defined as "every step in the procedure, mandated by the law or by court regulation, which demands interaction between the parties or between them and the judge or court officer, such as filing a motion or attending a hearing." In the neighborhood model, there are very few such actions so that the lower the number of in- 
dependent procedural actions, the closer the respective system to the idealized neighborhood model.

Additionally, Djankov et al. (2003) produce two numbers reflecting the number of days needed to have the tenant evicted and the bounced check paid. This indicator was produced in cooperation with Lex Mundi, an association of international law firms, and is available for 109 countries.

Djankov et al.'s study can be criticized on a number of grounds. The benchmark for their evaluations, i.e., their neighborhood model, might be adequate for resolving simple disputes but might be completely inadequate when the dispute involves complex contracts. Moreover, they seem to assume that speed in judicial decision making needs to be maximized. However, some decisions might warrant an extensive fact-finding and evaluation process, which requires a certain amount of time. Their "data" are not based on facts, but on hypothetical cases: they do not measure how courts actually perform but how law firms around the world believe that their local courts would perform were they to decide the two paradigmatic cases.

Djankov et al. find procedural formalism to be systematically higher in civil than in common law countries. Moreover, formalism is associated with a higher expected duration of judicial proceedings, more corruption, less consistency, less honesty, less fairness in judicial decisions, and inferior access to justice. Given these disadvantages, we would expect, ceteris paribus, that countries characterized by high levels of procedural formalism should also experience lower economic growth rates. To assess the impact of the formalism variables, we include these indicators in our growth regressions.

Thus, based on the theoretical analysis, we are faced with two competing views. Whereas Djankov et al. constantly suspect the government of wanting to interfere in conflict resolution, our approach interprets many judicial procedures as contributing to judicial accountability. We now proceed to test these hypotheses empirically.

\section{Data Description}

To estimate the effects of judicial procedure on economic outcomes, we need a number of variables that can serve as proxies for the various elements of judicial procedure. As previous studies have shown, formal legal enactments and their actual enforcement are often worlds apart. It is, therefore, desirable to employ indicators for de facto rather than de jure judicial procedures.

Hathaway (2002) creates a Fair Trial Index that contains 10 procedural aspects, namely: (1) an independent and impartial judiciary, (2) the right to counsel, (3) the right to present a de- 
fense, (4) the presumption of innocence, (5) the right to appeal, (6) the right to an interpreter, (7) the absence of ex post facto laws, (8) the right to a public trial, (9) the right to have prior notice of the charges that will be made, and (10) timeliness of court action. ${ }^{1}$

All 10 features can be expected to increase the predictability of the behavior of judges and other representatives of the judiciary; however, perhaps some could use a more detailed explanation. In the European Convention on Human Rights, only three of these procedural aspects are not explicitly mentioned in conjunction with criminal charges, namely: (1) the right to an independent and impartial judiciary, (8) the right to a public trial, and (10) timeliness. Some elements only make sense in the context of criminal cases, such as (3) the right to present a defense, (4) the presumption of innocence, and (9) the right to prior knowledge of the charges.

Ex ante, it is unclear how procedures in criminal cases affect the number of transactions, investment in physical capital, and degree of specialization in human capital. However, we conjecture that to the extent these procedural rights are directly applicable to noncriminal cases, compliance with them in the criminal context will be highly correlated with compliance in both public and private law. Moreover, it can be argued that higher degrees of fairness in criminal cases will increase the confidence people have in the court system in general.

In constructing her indicator, Hathaway (2002) relies on the Human Rights Reports issued by the U.S. State Department. These reports are verbal and thus have to be quantified. Two research assistants coded the data and intercoder reliability is $82 \%$. The indicator is available for six years $(1985,1988,1991,1994,1997$, and 2000) and for as many as 160 countries. Countries are coded " 0 " if the respective right is always enforced, " 0.5 " if it is sometimes enforced, and " 1 " if it is never or not enforced. To make the interpretation more intuitive, we recoded the variables such that larger values correspond to stronger enforcement.

The indicators are clearly constructed to reflect actual enforcement of judicial procedures. The focus is restricted to civilian trials, i.e., military court proceedings are not taken into account. Apart from this restriction, the Hathaway indicators refer to all kinds of trials and include civil as well as penal and administrative cases.

We find that there is substantial variation of indicators across time within specific countries. To reduce the likelihood that singular events unduly influence the results, we use the average over all the years for which data are available.

\footnotetext{
${ }^{1}$ Hathaway selected these issues because they figure prominently in the various human rights conventions: the International Covenant on Civil and Political Rights, the American Convention on Human Rights, the Euro-
} 
An additional problem with the data is their source. Although the State Department reports are based on reported facts, subjective evaluation by the staff of U.S. embassies still plays a role and the reports could also be used to serve political ends, such as justifying U.S. development aid to certain states. However, it has been noted (Poe et al., 1999) that the annual reports of Amnesty International and those of the State Department have been steadily converging and are no longer very different in their evaluation of most states. The coarse coding constitutes yet another potential problem. In particular, the "sometimes" category could contain strong variation, ranging from one-time enforcement of a procedural right to sporadic but fairly common enforcement.

Despite these problems, the Hathaway data have a number of advantages over the Lex Mundi data. For one, they are based on thousands of real-world court cases instead of on only two hypothetical cases, as in the Lex Mundi data. ${ }^{2}$ The Hathaway data reflect factual experience over a decade and a half, whereas the Lex Mundi data are a snapshot of what a number of advocates believed to be likely at one point of time. If a country had just implemented some judicial reforms, the expected improvements might already be reflected in their answers.

Finally, Djankov et al. attribute the variation of results across countries to differences in legal origins. To test this view, we include indicators for legal origin in our study.

Table A1 in the Appendix sets out descriptive statistics of the legal indicators under consideration, namely, those derived from Hathaway (2002), Djankov et al. (2003), and the legal origin variables based on La Porta et al. (1999). The variation in "no ex post facto laws" and "right to an interpreter" is extremely low and to preserve degrees of freedom, we exclude these two judicial elements from the following analysis. ${ }^{3}$

pean Convention on Human Rights (more precisely, the Convention for the Protection of Human Rights and Fundamental Freedoms), and the African Charter on Human and People's Rights.

2 In fact, cashing bounced checks does not seem to be a very typical problem either in highly or less highly developed countries.

3 Note that we ran a number of robustness checks to ensure that the exclusion of these variables does not affect the results and that they are never statistically significant. 


\section{Estimation Approach and Interpretation of Results}

We test our basic hypothesis with a standard growth model that explains the average growth rate of per capita GDP for 67 countries over the period 1985-2003 (a list of the countries can be found in Table A5 in the Appendix). ${ }^{4}$

$\mathrm{Y}=\mathrm{B} \alpha+\mathrm{C} \gamma+\mathrm{H} \beta+\mathrm{D} \delta+\mathrm{L} \lambda+\varepsilon$

where: $\mathrm{Y}=$ Vector of growth rates in $\%$,

$\mathrm{B}=$ Matrix of basic explanatory variables,

$\alpha=$ Vector of coefficients basic explanatory variables,

$\mathrm{C}=$ Matrix of control variables,

$\gamma=$ Vector of coefficients on additional control variables,

$\mathrm{H}=$ Matrix of procedural justice indicators,

$\beta=$ Vector of coefficients on procedural justice variables,

$\mathrm{D}=$ Matrix of the degree of judicial formalism variables,

$\delta=$ Vector of coefficients on the degree of judicial formalism variables,

$\mathrm{L}=$ Matrix of the legal origin variables,

$\lambda=$ Vector of coefficients on the legal origin variables,

$\varepsilon \quad=$ Vector of errors.

Given the relatively short sample period of about 15 years for the judicial indicators (1985 to 2000), we decided to concentrate on the average growth rate. Even cutting the period in half to generate a panel leads to severe problems of unaccounted business cycle variations. Moreover, the Djankov et al. variables on judicial formalism are available for only one point in time.

The standard explanatory variables combined in matrix B are the ratio of investments to GDP, the real GDP in 1985 U.S. dollars, the rate of population growth in percent, and the share of persons over 25 years with a secondary education in percent (Barro and Lee 2000). ${ }^{5}$

\footnotetext{
4 Although Hathaway provides data for 160 countries, we are able to estimate our model for only 67 countries because we include only those countries also covered by Lex Mundi and for which we information for the full set of control variables.

5 Using a modified version of the extreme bounds analysis suggested by Leamer (1978), de Haan and Sturm (2000) find investment, initial income, and the degree of schooling to be robustly linked to economic growth. In our sample, and applying a general-to-specific modeling strategy, it is population growth that is robustly related to growth, with schooling much less important.
} 
Matrix $\mathrm{C}$ contains the control variables, which are grouped into different categories. Regional dummies are used for Africa, Asia, the Middle East, South America, the Pacific Islands, and transition countries. Economic control variables include openness, defined as the sum of imports and exports divided by GDP (average over the period 1985-2003 in percent), inflation (growth rate of the GDP deflator over the period 1985-2003 in percent), and government expenditure in relation to GDP (average over the period 1985-2003 in percent), as suggested by Barro (1997). Additionally, a dummy for OECD membership is used to control for omitted influences related to the phase of economic development. Political and institutional control variables are the degree of democratization (POLITY IV), the degree of economic freedom (Fraser Institute, average over 1985-2003), the degree of freedom of the press (Freedom House 2002), political rights and civil liberties (also from Freedom House), and the occurrence of governments controlled by the military (Banks 2004). All variables without a specific reference are taken from the Penn World Tables Version 6.2 (Heston et al. 2006).

Matrix H contains the average over the judicial indicators provided by Hathaway (2002) for the time period 1985-2000. To make interpreting this variable more intuitive, we multiply the outcome of the original coding by -1 , which implies that larger values are associated with stronger enforcement of the respective legal aspect.

Matrix D contains the seven indicators proposed by Djankov et al (2003): professional vs. laymen, written vs. oral elements, legal justification, statutory regulation of evidence, control of superior review, engagement formalities, and independent procedural actions. These indicators are available for each of the stylized cases studied in Djankov et al.- eviction of a tenant and collection of a check. In addition, Djankov et al. combine these indicators into simple indices for each of the two cases. These indices are never significant in our specifications and, for brevity reasons, we do not report their results.

Matrix L contains the legal origin variables proposed by La Porta et al. (1999), namely, English, French, German, Scandinavian, or Socialist legal origin. The authors argue that these are "deep" institutional variables that help explain cross-country economic performance.

It is interesting to study the correlations of the four groups of judicial variables (procedural variables, formalism eviction of a tenant, formalism collecting a check, and legal origin). Tables A2 to A4 in the Appendix provide the respective Pearson correlation coefficients and the outcome of statistical significance tests. None of the correlations are above 0.45 and many are insignificant. However, there are three noteworthy patterns. First, the procedural aspect "timeliness" is positively related to most formalism indicators, which suggests that increasing formalism is associated with less timely decisions. Second, the formalism indicator "independent 
procedural actions" is positively correlated with most procedural indicators. This could be interpreted as meaning that more independent procedural actions lead to a less strict adherence to legal procedures. Causality could run in the other direction, but it is not obvious why a weaker adherence to judicial procedures should increase the number of independent procedural actions. Third, countries with a Scandinavian legal origin display a particularly strict adherence to procedural norms.

Since bivariate correlations are often misleading, we concentrate on multivariate procedures to explain cross-country variation in average GDP growth rates. Regarding the econometric methodology, we apply a general-to-specific modeling approach (Hendry 1993), which has several advantages compared to the typical group-by-group analysis of indicators: it ensures that potential estimation biases are low, it allows for consistent testing procedures, and it fully considers the interaction of the explanatory variables. It would be desirable to estimate Equation (1) using all the available data, but given our limited number of degrees of freedom, we opt for a general-to-specific modeling approach within models that have a priori restrictions on Equation (1).

We present the outcome of consistent testing-down approaches for the following four models:

$$
\begin{aligned}
& \mathrm{Y}=\mathrm{B} \alpha+\mathrm{C} \gamma+\mathrm{L} \lambda+\varepsilon, \\
& \mathrm{Y}=\mathrm{B} \alpha+\mathrm{C} \gamma+\mathrm{H} \beta+\varepsilon, \\
& \mathrm{Y}=\mathrm{B} \alpha+\mathrm{C} \gamma+\mathrm{H} \beta+\mathrm{D}_{\mathrm{a}} \delta_{\mathrm{a}}+\varepsilon,
\end{aligned}
$$

where: $D_{a}=$ Matrix of the degree of judicial formalism variables for eviction of tenant,

$\delta_{\mathrm{a}}=$ Vector of coefficients on the degree of judicial formalism variables for eviction of tenant, and

$\mathrm{Y}=\mathrm{B} \alpha+\mathrm{C} \gamma+\mathrm{H} \beta+\mathrm{D}_{\mathrm{b}} \delta_{\mathrm{b}}+\varepsilon$,

where: $D_{b}=$ Matrix of the degree of judicial formalism variables for bounced checks,

$\delta_{\mathrm{b}}=$ Vector of coefficients on the degree of judicial formalism variables for bounced checks.

Since we still have many regressors in Equations (2)-(5), there is the danger that our final parsimonious models are not encompassing models, as inference may be path-dependent. Based on the work by Hoover and Perez (1999), Hendry and Krolzig (1999) develop a model reduction algorithm, which is powerful in recovering the underlying data generating process (DGP) according to a wide range of Monte-Carlo studies. Statistical tests indicate that the unrestricted models based on Equations (2)-(5) are acceptable representations of the DGP, as they pass all relevant diagnostics (results available upon request), which allows estimations with 
OLS. To economize on space, we present only the parsimonious models that emerge from the general-to-specific modeling process at a nominal significance level of 5\%.

Table 1 sets forth the results of estimating Equation (2). Column 1 contains the variables that remain after the reduction process and the elimination of which would violate a statistical test. The coefficient estimates and standard errors (SE) are given in Columns 2 and 3, respectively. Column 4 contains partial $\mathrm{R}^{2} \mathrm{~s}$ and Column 5 has estimates of the elasticities of the variables measured at their respective means. Only a few of the initial 22 variables survive the testingdown process.

Table 1: Specific model for the per capita GDP growth rate in \% (Equation (2)) Included judicial variables: Legal origins

\begin{tabular}{lcccc}
\hline Remaining variables & Coeff. & SE & Partial-R & Elasticities \\
\hline Initial GDP in 1985 in US \$ & $-0.0016^{* *}$ & 0.0003 & 0.33 & -1.07 \\
Investment to GDP ratio in \% & $0.930^{* *}$ & 0.221 & 0.23 & 1.29 \\
Population growth in \% & $-1.072^{* *}$ & 0.211 & 0.26 & -1.18 \\
Average inflation rate & $-0.239^{*}$ & 0.095 & 0.10 & -0.05 \\
Economic freedom index & $5.470^{*}$ & 2.057 & 0.11 & 2.87 \\
South America & $-8.559^{* *}$ & 2.794 & 0.14 & \\
Constant & -6.226 & 10.98 & 0.01 &
\end{tabular}

\begin{tabular}{|l|l|}
\hline \hline (1) No of observations & 67 \\
\hline (2) SE equation & 9.14 \\
\hline (3) $\mathrm{R}^{2}$ & 0.57 \\
\hline (4) Model selection criterion: Adj. $\mathrm{R}^{2}$ & 0.526 \\
\hline (5) Model selection criterion: Hannan-Quinn & 7.452 \\
\hline (6) Joint test remaining variables & $\mathrm{F}(6,60)=13.2^{* *}$ \\
\hline (7) Testing-down from general model & $\mathrm{F}(16,44)=0.82$ \\
\hline (8) Heteroscedasticity test & $\mathrm{F}(11,48)=0.96$ \\
\hline (9) Normality test & $\mathrm{Chi}^{2}(2)=2.42$ \\
\hline (10) RESET test & $\mathrm{F}(1,59)=2.36$ \\
\hline
\end{tabular}

Notes: Estimation method: OLS. The elasticity estimates are computed at the means of the respective variables. Low values of the judicial variables indicate that the respective right is usually enforced. $*(* *)$ indicates significance at a $5 \%(1 \%)$ level.

The lower panel of Table 1 contains relevant diagnostic information. First, in Line (7), the test does not reject the removal of 16 variables. The remaining variables are highly significant as a 
group, as can be seen in Line (6). Second, the model explains about $57 \%$ of the variation in the cross-country growth rates. To foster the comparison of final models across the four specifications in Equations (2)-(5), we compute the Hannan-Quinn criterion (including the loglikelihood constant) and the adjusted $\mathrm{R}^{2}$. The Hannan-Quinn criterion is consistent and lies between the criteria proposed by Akaike and Schwarz with regard to penalizing a higher number of variables in the model. The adjusted $\mathrm{R}^{2}$ is not as well-founded in statistical theory but is widely used in empirical applications. For a valid estimation process, it is important to ensure the adequacy of the underlying statistical assumptions. The model passes tests for heteroscedasticity (White (1980), using squares), normality (Jarque and Bera (1987), with a small-sample correction), and misspecification (RESET test based on Ramsey (1969) using squares of the fitted values).

The impact of the variables that survive the testing-down process of Equation (2) is in line with our theoretical priors. Regarding the economic variables, there is a negative effect of initial income, a positive effect of investments on growth, and a negative effect of the population growth rate on growth. In addition, we obtain a negative impact of the inflation rate on growth. In interpreting these findings, we first conclude that there is evidence of conditional income convergence. ${ }^{6}$ Every $\$ 1,000$ additional per capita income reduces the average growth rate over the full period by about 1.6 percentage points. ${ }^{7}$ Second, a 1 percentage point higher share of investment in GDP raises the average growth by about 0.9 percentage points. Third, an increase of the population growth rate by 1 percentage point lowers the GDP growth rate by about 1.1 percentage points. Fourth, 1 percentage point less average inflation generates 0.25 percentage points more average growth. In addition to the core economic variables, the economic freedom index is significant, indicating that greater freedom leads to an increase in the average growth rate. Growth in the South American countries is about 9 percentage points below the sample average. An important finding, given the focus of our paper, is that none of the legal origin variables are significant, meaning that legal origin does not have a significant influence on the average growth rate in our sample. ${ }^{8}$

It is interesting to compare the relative importance of the variables in the model. Partial $\mathrm{R}^{2} \mathrm{~S}$ give the explanatory power of variables after the impact of the other variables has been taken into account. Here, we find that the three variables that are directly derived from the growth

\footnotetext{
6 We do not find evidence for unconditional convergence in our sample (results available upon request).

7 This is not a trivial impact, as per capita income varies from about $\$ 700$ to almost $\$ 25,000$ per year and the mean of the average per capita growth rates is about 12 percent.
} 
model have the highest relative explanatory power. Since the dimensions of some variables employed in the regression are arbitrary, estimated elasticities at the sample mean are shown in the last column of Table 1 . With a value of 2.9 , the economic freedom index has the highest elasticity. The effects of the three economic variables derived from the growth model are also rather elastic, whereas the impact of the inflation rate is highly inelastic.

In a next step, we estimate Equation (3) using the Hathaway-coded indicators of procedural aspects of national legal systems. Table 2 contains the outcome of the testing-down process from the general model with 27 variables.

Table 2: Specific model for the per capita GDP growth rate in \% (Equation (3)) Included judicial variables: Procedural indicators

\begin{tabular}{lcccc}
\hline Remaining variables & Coeff. & SE & Partial- ${ }^{2}$ & Elasticities \\
\hline Initial GDP in 1985 in US \$ & $-0.0014^{* *}$ & 0.0003 & 0.35 & -0.97 \\
Investment to GDP ratio in \% & $0.603^{* *}$ & 0.190 & 0.15 & 0.83 \\
Population growth in \% & $-1.143^{* *}$ & 0.197 & 0.37 & -1.25 \\
Presumption of innocence & $-34.10^{* *}$ & 6.813 & 0.30 & -0.42 \\
Timeliness & $18.63^{* *}$ & 4.244 & 0.25 & 0.54 \\
Military control & $-6.876^{*}$ & 3.072 & 0.08 & \\
South America & $-5.392^{*}$ & 2.663 & 0.07 & \\
Transition countries & $-14.27^{*}$ & 6.201 & 0.08 & \\
Constant & $36.71^{* *}$ & 5.502 & 0.43 & \\
\end{tabular}

\begin{tabular}{|l|l|}
\hline \hline (1) No of observations & 67 \\
\hline (2) SE equation & 7.67 \\
\hline (3) $\mathrm{R}^{2}$ & 0.71 \\
\hline (4) Model selection criterion: Adj. $\mathrm{R}^{2}$ & 0.666 \\
\hline (5) Model selection criterion: Hannan-Quinn & 7.154 \\
\hline (6) Joint test remaining variables & $\mathrm{F}(8,58)=17.5^{* *}$ \\
\hline (7) Testing-down from general model & $\mathrm{F}(19,39)=0.41$ \\
\hline
\end{tabular}

\footnotetext{
8 Due to perfect collinearity, the regional dummy for transition countries makes it impossible to include the indicator for socialist legal origin.
} 


\begin{tabular}{|l|l|}
\hline (8) Heteroscedasticity test & $\mathrm{F}(14,43)=1.23$ \\
\hline (9) Normality test & $\mathrm{Chi}^{2}(2)=0.06$ \\
\hline (10) RESET test & $\mathrm{F}(1,57)=0.30$ \\
\hline
\end{tabular}

Notes: Estimation method: OLS. The elasticity estimates are computed at the means of the respective variables. ${ }^{*}(*)$ indicates significance at a $5 \%(1 \%)$ level.

The removal of 19 variables from the general model is accepted, as is evident from the F-test reported in Line (7) of the lower panel of Table 2. We observe a substantial improvement in explanatory power - the coefficient of determination rises from 0.57 in the previous model to 0.71 and the two model selection criteria displayed in the table also improve. The diagnostic tests do not indicate any statistical problems.

Of the remaining variables, those that are directly derived from the growth model are again highly significant, but the absolute impact of these variables has decreased, except for population growth. These changes are also reflected in the relative impact of these variables in terms of partial $\mathrm{R}^{2} \mathrm{~s}$ and elasticities. In contrast, neither economic freedom nor inflation remain in the final specification. There are now significant additional control variables, as transition countries, as well as those under military rule, experience below average economic growth. Two judicial variables - timeliness and presumption of innocence - have a significant effect on income growth. Those economies characterized by relatively longer judicial processes exhibit a lower growth rate. The presumption of innocence variable has a negative sign, indicating that this particular procedural aspect may have costs in terms of lower economic growth. Regarding the relative impact of the judicial variables on the average growth rate, we find a higher partial $\mathrm{R}^{2}$ for presumption of innocence. Note that the added explanatory power of both judicial variables is substantial and similar to those of the core economic variables. However, both procedural indicators have an inelastic impact on the average economic growth rate, with timeliness being somewhat more elastic.

In the next step, we add the formalism indicators to the model and estimate the general model outlined in Equation (4), the results of which are recorded in Table 3. Of the 34 variables in the general model, only 10 remain significant. The diagnostic statistics are again acceptable. With an $\mathrm{R}^{2}$ of 0.75 , we observe a further increase in fit and there is also an improvement in the model selection criteria. The three economic core variables are still significant and we also find that countries in South America, those undergoing an economic transition, and/or those under military rule show a lower growth rate. Timeliness and presumption of innocence are again significant, and another procedural indicator is also of relevance: stronger implementa- 
tion of the right to counsel has a positive impact on the economic growth rate. ${ }^{9}$ We interpret this finding as evidence for our view that procedures increase the transparency of judicial decisions as lawyers can be expected to insist on the proper application of the relevant norms, which again increases judges' accountability to the law.

Table 3: Specific model for the per capita GDP growth rate in \% (Equation (4))

\section{Included judicial variables: Procedural indicators and formalism indicators (tenant)}

\begin{tabular}{lcccc}
\hline Remaining variables & Coeff. & SE & Partial- ${ }^{2}$ & Elasticities \\
\hline Initial GDP in 1985 in US \$ & $-0.0018^{* *}$ & 0.0003 & 0.43 & -1.17 \\
Investment to GDP ratio in \% & $0.664^{* *}$ & 0.190 & 0.18 & 0.92 \\
Population growth in \% & $-0.993^{* *}$ & 0.195 & 0.32 & -1.09 \\
Presumption of innocence & $-37.70^{* *}$ & 6.682 & 0.36 & -0.46 \\
Timeliness & $18.00^{* *}$ & 4.162 & 0.25 & 0.52 \\
Right to counsel & $19.80^{*}$ & 8.304 & 0.09 & 0.51 \\
Written vs. oral & $13.51^{*}$ & 6.174 & 0.08 & 0.88 \\
Military control & $-8.241^{* *}$ & 2.945 & 0.12 & \\
South America & $-8.687^{* *}$ & 2.834 & 0.14 & \\
Transition countries & $-14.20^{*}$ & 5.891 & 0.09 & \\
Constant & $32.58^{* *}$ & 6.186 & 0.23 & \\
& & & & \\
\end{tabular}

\begin{tabular}{|l|l|}
\hline \hline (1) No of observations & 67 \\
\hline (2) SE equation & 7.26 \\
\hline (3) $\mathrm{R}^{2}$ & 0.75 \\
\hline (4) Model selection criterion: Adj. $\mathrm{R}^{2}$ & 0.701 \\
\hline (5) Model selection criterion: Hannan-Quinn & 7.095 \\
\hline (6) Joint test remaining variables & $\mathrm{F}(10,56)=16.5^{* *}$ \\
\hline
\end{tabular}

\footnotetext{
9 This finding underlines the advantages of our econometric methodology compared to the widely used method of a blockwise comparison of variables, as this variable is only significant in conjunction with the formalism variables. If we had only compared the impact of legal indicators group-by-group, we would not have been able to uncover this effect.
} 


\begin{tabular}{|l|l|}
\hline (7) Testing-down from general model & $\mathrm{F}(24,32)=0.30$ \\
\hline (8) Heteroscedasticity test & $\mathrm{F}(18,37)=0.62$ \\
\hline (9) Normality test & $\mathrm{Chi}^{2}(2)=0.20$ \\
\hline (10) RESET test & $\mathrm{F}(1,55)=0.24$ \\
\hline
\end{tabular}

Notes: Estimation method: OLS. The elasticity estimates are computed at the means of the respective variables. $*(* *)$ indicates significance at a $5 \%(1 \%)$ level.

The final judicial variable of significance comes from the set of formalism indicators put forward by Djankov et al. (2003). Countries that rely more on written as opposed to oral court processes achieve a higher growth rate. We would interpret this as suggesting that in modern economies judicial problems are often quite complex and unlikely to be resolved by an oral discussion between laymen, as argued by the "neighborhood" model proposed by Djankov et al. Instead, these problems require substantial assistance from professional lawyers and written documentation of the court proceedings undertaken to resolve them. Note that when estimating the impact of the procedural variables in a larger sample of 80 countries without the formalism variables, right to appeal appears to be growth enhancing. Arguably, reevaluation of a court decision by a higher-ranking court is made considerably more feasible when the first legal process has been extensively documented.

In terms of the relative importance of the variables in Table 3, the three economic core variables plus the two procedural variables "timeliness" and "presumption of innocence" have the highest partial $\mathrm{R}^{2} \mathrm{~s}$. In contrast, the additional legal variables — right to counsel and written vs. oral-have much lower partial $\mathrm{R}^{2} \mathrm{~s}$. This pattern is not reflected in the estimated elasticities, as growth reacts more elastically to marginal changes in the formalism indicator than to changes in the procedural variables. We conclude from estimating the reduced model of Equation (4) that growth-enhancing legal systems are characterized by striking a balance between making quick decisions and taking into account the increasing judicial complexity of many cases by providing adequate institutions.

Finally, we analyze Equation (5), where the Hathaway procedural variables are included together with the formalism indicators computed for collecting a check. This time, the reduction process had more ambiguous results, yielding three models as the outcome of different reduction paths. One of the models includes the regional dummy South America instead of the judicial indicator "independent procedural actions." Another model substitutes the regional dummies for South America and transition countries with the economic freedom index. However, both model selection criteria - the adjusted $\mathrm{R}^{2}$ and the Hannan-Quinn information criterion (as well as Akaike and Schwarz) — clearly prefer the model presented in Table 4. The coefficient of determination of this model is lower compared to that of the previous model, 
which would also be preferred in terms of the model selection criteria. None of the diagnostic tests indicates a violation of statistical assumptions. The core economic variables and the dummies have not changed much.

With regard to the procedural variables, we again obtain significant estimates for presumption of innocence and timeliness. This time, another formalism variable survives the testing-down process, namely, the number of independent procedural actions in the collection of a bounced check. The larger this number, the lower the average per capita growth rate. This variable reflects the negative growth effects of legal actions that require an undue amount of time and money. Evaluating the relative importance of the variable "independent procedural actions," we note that it has neither a particularly large partial $\mathrm{R}^{2}$ nor a high elasticity.

Table 4: Specific model for the per capita GDP growth rate in \% (Equation (5)) Included judicial variables: Procedural indicators and formalism indicators (check)

\begin{tabular}{lcccc}
\hline Remaining variables & Coeff. & SE & Partial-R & Elasticities \\
\hline Initial GDP in 1985 in US \$ & $-0.0015^{* *}$ & 0.0003 & 0.36 & -0.98 \\
Investment to GDP ratio in \% & $0.689^{* *}$ & 0.190 & 0.19 & 0.95 \\
Population growth in \% & $-1.072^{* *}$ & 0.120 & 0.33 & -1.18 \\
Presumption of innocence & $-35.63^{* *}$ & 6.831 & 0.32 & -0.44 \\
Timeliness & $19.15^{* *}$ & 4.107 & 0.27 & 0.55 \\
Independent procedural actions & $-12.07^{*}$ & 5.654 & 0.07 & -0.25 \\
Military control & $-6.776^{*}$ & 3.043 & 0.08 & \\
Transition countries & $-13.17^{*}$ & 6.165 & 0.07 & \\
Constant & $36.19^{* *}$ & 5.484 & 0.43 &
\end{tabular}

\begin{tabular}{|l|l|}
\hline \hline (1) No of observations & 67 \\
\hline (2) SE equation & 7.64 \\
\hline (3) $\mathrm{R}^{2}$ & 0.71 \\
\hline (4) Model selection criterion: Adj. $\mathrm{R}^{2}$ & 0.668 \\
\hline (5) Model selection criterion: Hannan-Quinn & 7.146 \\
\hline (6) Joint test remaining variables & $\mathrm{F}(8,58)=17.6^{* *}$ \\
\hline (7) Testing-down from general model & $\mathrm{F}(26,32)=0.50$ \\
\hline (8) Heteroscedasticity test & $\mathrm{F}(15,42)=0.99$ \\
\hline
\end{tabular}




\begin{tabular}{|l|l|}
\hline (9) Normality test & $\mathrm{Chi}^{2}(2)=0.02$ \\
\hline$(10)$ RESET test & $\mathrm{F}(1,57)=0.08$ \\
\hline
\end{tabular}

Notes: Estimation method: OLS. The elasticity estimates are computed at the means of the respective variables. ${ }^{*}(*)$ indicates significance at a $5 \%(1 \%)$ level.

In a final evaluation of the empirical analysis, we consider whether there are particular outliers in the sample. Judging from the model selection criteria, Equation (4) is the best specification. Figure 1 displays the original series and the fitted values when countries are ordered alphabetically (see Table A5 in the Appendix for a list of included countries).

Figure 1: Actual average growth rates and fitted values based on model in Table 4

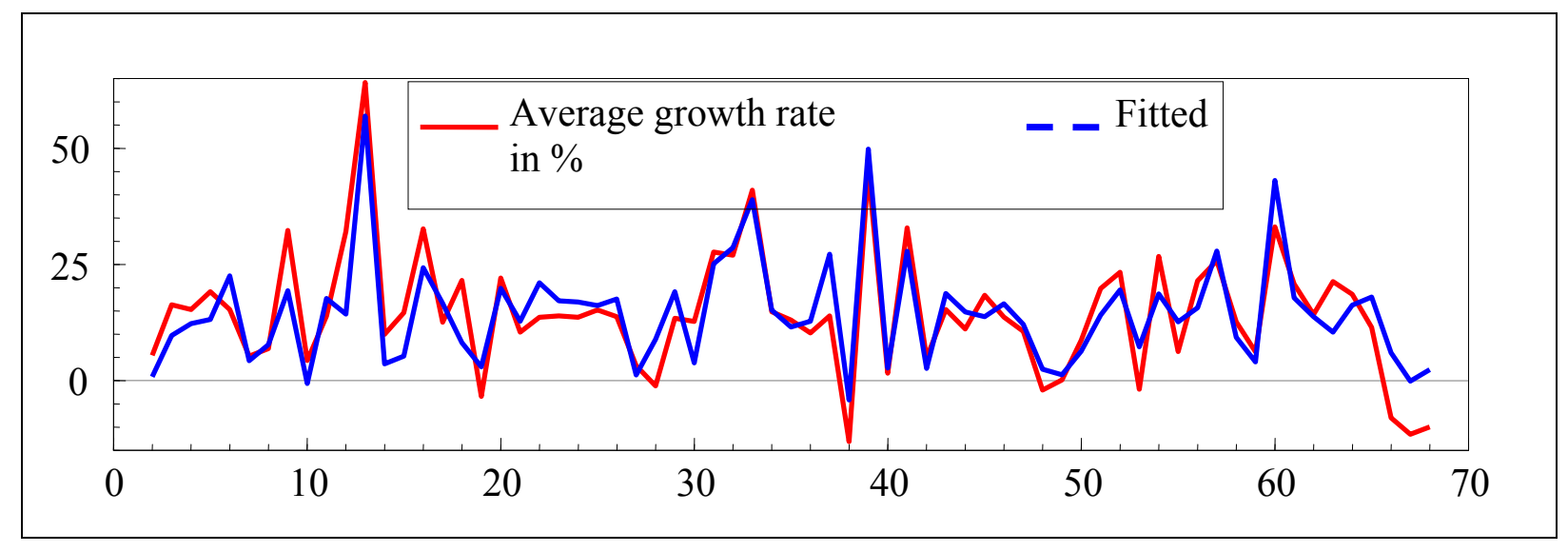

According to Figure 1, model fit is good and there are no strong outliers. However, it could be that the results are not robust over different groups of countries. In particular, there could be differences between high- and low-income countries. To address this concern, we order the data from poor to rich countries using initial per capita incomes and reestimate the model recursively. Figure 2 presents the one-step ahead residuals with significance bands based on + 2 standard errors.

Figure 2: Recursive estimation after ordering from low- to high-income countries: One step-residuals with $+/-2$ SEs 


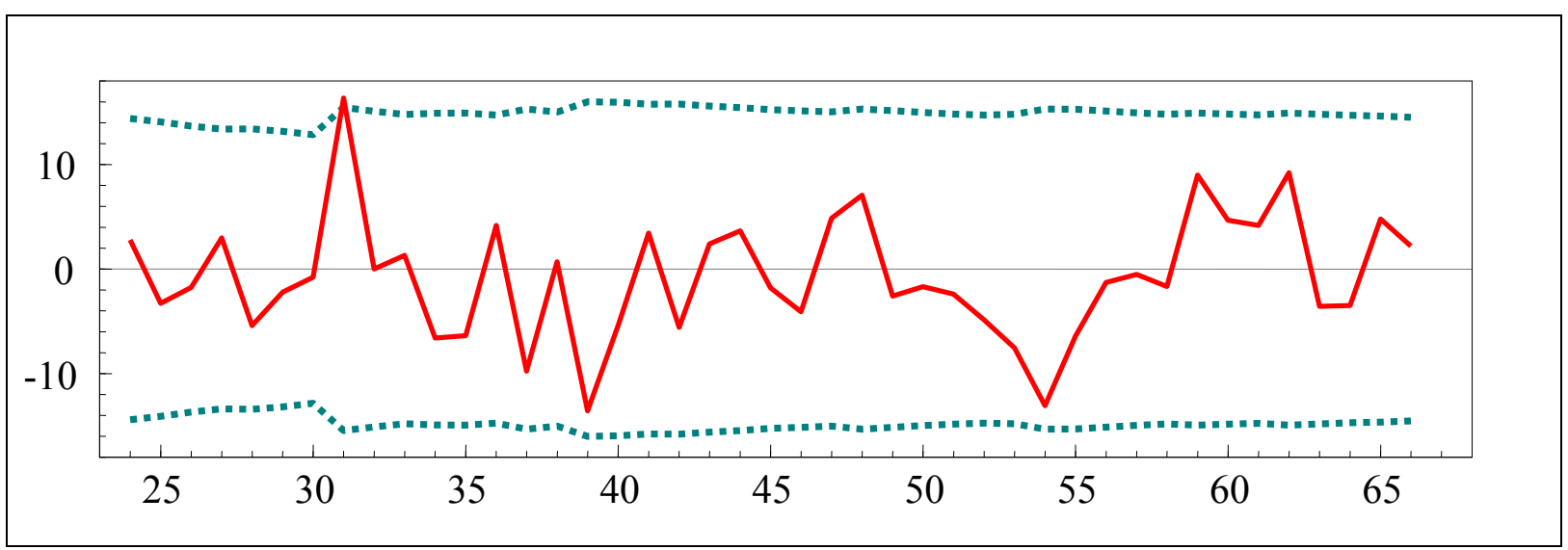

Overall, Figure 2 demonstrates no sign of instability, as the error bands are quite constant over the sample and the residuals are almost randomly distributed. ${ }^{10}$

\section{Why does the presumption of innocence reduce economic growth?}

Above we show that the factually realized degree of presuming innocence has a negative effect on economic growth, a result requiring further exploration. First, it is necessary to briefly discuss the policy consequences of this finding. Second, we will outline one possible transmission channel from this judicial principle to economic growth. Third, we investigate an alternative transmission channel running via social trust, which we support by additional empirical evidence.

Tampering with the presumption of innocence runs against our normative principles and giving policy advice based on our results of how this factor affects economic growth does not feel comfortable. However, there really is no problem with retaining this judicial procedure. All societies make sacrifices of material goods to help maintain particular normative principles. Thus, while economic growth might be enhanced by the abolition of this procedural principle, we do not argue for such a course of action as normative costs would be too high. The first transmission channel we explore as to how this presumption of innocence negatively impacts economic growth takes us to the strictness of the standards that must be fulfilled before a person is convicted: the stronger the presumption of innocence is implemented, the harder it is to overcome, which in practical terms, means it costs more and takes more time. That the presumption of innocence is negatively correlated with growth could mean that the extra costs of running a judicial system operating under this presumption are not compensated for by other economic gains, such as predictability of the state. Posner $(1995,77)$ is very explicit: "Much pious denial to the contrary, coercion, unless taken to the brutal extreme at

10 There is one observation (Chile) that is marginally significant. 
which it will induce an innocent person to confess, is a cheap and effective method of criminal investigation." Thus, in this interpretation, the timeliness indicator, the formalism indicator "number of independent procedural actions," and this variable may characterize particularly slow judicial processes and this delay in decisions comes at the cost of lower income growth by increasing uncertainty and transaction costs within the economy.

A decision on the realized level of presumption of innocence is also a decision on how to balance type I against type II errors: with a low level, a number of innocent people will be wrongly convicted (call this type I error) whereas with a high level, a number of guilty people will be wrongly acquitted (call this type II error). Potential effects of type I errors are that the legitimacy of the judicial system will suffer and that productive people are no longer productive (due to their incarceration), which would lead to a decrease in growth. A potential effect of type II errors is that criminals remain active. If it is common knowledge that criminals remain at large, citizens might increase private spending to protect themselves. Given our results, it appears that type I errors are less costly than type II errors. In addition, a low degree of the presumption of innocence could be interpreted as a signal to all citizens that the government is "tough" on all types of crime, thus providing an incentive to abstain from crime, leading to a lower crime rate, which may be conducive to economic growth. Singapore can be viewed as an example of a state with such a policy.

However, there is a competing transmission channel that could account for the negative effect on economic growth of the presumption of innocence. The presumption of innocence makes it harder to convict criminals. Consequently, there will be more criminals at large within the society, leading to a relatively lower degree of trust. Trust, however, is known to reduce the cost of economic transactions, thereby leading to more economic activity. ${ }^{11}$ In addition, having more criminals in society may be indicative of a fewer economic transactions being officially recorded (e.g., black market activity), implying that official income statistics will be downward-biased.

To test this conjecture, in a first step we compute the correlation of an indicator for trust within society, based on the World Value Survey (WVS), with the presumption of innocence variable. We find a small but supportive correlation between the variables (correlation coefficient is -0.19 for the sample based on the WVS in 1981 and -0.07 for an average over three waves, 1981, 1990, and 1995/1997). ${ }^{12}$

\footnotetext{
11 Durlauf and Fafchamps (2005) is a recent survey of the relevant literature.

12 As an indicator for general trust, we use the mean of the answers coded as 0/1-dummy for each country to the question "Can people be trusted?"
} 
In the second step, we include general trust and an interaction variable between trust and presumption of innocence as additional regressors into the model displayed in Table 2. To preserve a reasonable number of observations, we focus on the average over the three waves of the WVS. ${ }^{13}$ Still, the sample size has been reduced by over $40 \%$, from 67 to 38 observations, due to missing information on the trust variable. Consequently, we increase the level of significance for the statistical tests to $10 \%$ (see Leamer 1978). Assessing the effect of the smaller sample size on the results in Table 2 indicates that while the significance of estimates has gone down as expected, previous results generally hold up well in this new setting. ${ }^{14}$ Reestimating this model including the trust variable and the interaction term, we obtain the results given in Table 5. The diagnostic tests have been omitted for the sake of brevity, but do not signal any statistical problems.

Including the trust variable and the interaction of trust with the presumption of innocence indicator, we find evidence supporting the hypothesis put forward above. First, trust has a positive (though in this specification not significant) impact on economic growth. Second, maintaining the presumption of innocence also influences growth in a positive and significant way. Third, the interaction of trust and presumption of innocence affects growth negatively. Thus, societies with little trust and a high degree of presumption of innocence are characterized by low growth rates, which is what our hypothesis would predict. Similar results can be derived for the presumption of innocence variable, the trust indicator, and their interaction when considering the models shown in Tables 3 and 4 (results omitted).

Table 5: Explaining the impact of the presumption of innocence variable in the framework of the model in Table 3

\begin{tabular}{lccccc}
\hline Variables & Coeff. & SE & Variables & Coeff. & SE \\
\hline Initial GDP in 1985 in US \$ & $-0.0015^{* *}$ & 0.0004 & Constant & $28.98^{* *}$ & 8.143 \\
Investment to GDP ratio in \% & 0.445 & 0.325 & Presumption of inno- & $35.72(*)$ & 19.14 \\
& & & cence & & \\
Population growth in \% & $-0.655\left(^{*}\right)$ & 0.322 & Trust & 18.17 & 12.62 \\
& & & & & \\
\hline
\end{tabular}

\footnotetext{
13 Note, however, that the core results also carry over to the trust data based on the 1981 wave only.

14 The effect of reducing the sample size does not affect the estimates given in Table 3, except that the military control dummy is no longer significant. Thus, the difference with regard to the coefficient on the presumption of innocence variable reported in Table 6 after the inclusion of the trust variable and the interaction term is not caused by reduction of the sample size.
} 


\begin{tabular}{|c|c|c|c|c|}
\hline Timeliness & $7.72(*)$ & 4.471 & $\begin{array}{c}\text { Interaction (Presump- } \\
\text { tion of innocence) by } \\
\text { (Trust) }\end{array}$ & $-119.5^{*} \quad 45.32$ \\
\hline Military control & 0.356 & 3.023 & (1) No of observations & 38 \\
\hline South America & -3.704 & 2.892 & (2) SE equation & 5.56 \\
\hline Transition countries & $-11.24(*)$ & 5.568 & (3) $R^{2}$ & 0.84 \\
\hline
\end{tabular}

Notes: Estimation method: OLS. $(*), *, * *$ indicates significance at a $10 \%, 5 \%$, and $1 \%$ level, respectively.

To assess the quantitative relationships in our data, we first assume that all three variables of interest are at their mean values. Under these circumstances, economic growth will be higher by a substantial 5.7 percentage points. However, when assuming a society characterized by a minimum degree of trust, while keeping the presumption of innocence at its mean value, the growth rate is only 2.5 percentage points above the sample average.

Hence, any policy advice involving changes in the presumption of innocence would need to take into account the specific social context. In other words, in addition to strong reservations from a normative point of view, one should take into account that the economic benefits of not implementing the presumption of innocence are conditional on a low degree of trust within a society.

\section{Conclusions and Outlook}

In this paper, we ask whether judicial procedural devices have any systematic consequences on economic growth. Two competing views on the likely effects of judicial procedure are discussed, one of which is Djankov et al.'s (2003), which argues that more regulated procedures (in their terms, higher degrees of procedural formalism) have a number of detrimental effects, such as higher levels of corruption, less fairness in judicial decisions, and inferior access to justice. Our own view of judicial procedure is diametrically opposed to theirs. We argue that at least some procedural devices are likely to improve the state's capacity to credibly commit to the promises contained in its laws. By making judicial decision making more transparent and judges more accountable to the law, more trade and investment is expected to take place, which will, in turn, be reflected in higher rates of economic growth.

Drawing on a dataset introduced by Hathaway (2002), as well as on the Lex Mundi data employed by Djankov et al., the conjecture that formalism always has adverse effects on growth 
can be rejected. Those variables that survived our rigorous statistical testing-down process allow us to paint a differentiated picture. (1) Written-as opposed to oral—procedures increase growth rates. Written procedures are certainly more costly in monetary terms than oral procedures, but the monetary costs are compensated for by gains in accountability. (2) A similar argument applies when the right to counsel is enforced. (3) Timeliness of court action also increases growth. Justice delayed is not only justice denied but also growth foregone. (4) Increasing the number of individual procedural actions will not only increase the resources needed for running the judicial system, but lengthen the judicial process. Our result indicates that there are no offsetting benefits, which is reflected in the negative effect that a higher number of individual procedural actions has on economic growth. (5) Finally, the negative effect that the presumption of innocence has on economic growth indicates that some procedural devices can indeed make legal processes cumbersome. However, we were able to show that in addition to any normative reservations we may have with regard to not implementing this procedural aspect, the resulting economic costs depend on the degree of trust in a society. Only in societies with a low degree of trust do we find the presumption of innocence to cause lower growth rates. In average societies, this legal principle actually increases the growth rate. It is also noteworthy that in contrast to the conjecture in Djankov et al., legal origins do not have a significant effect on economic growth. Thus, judicial procedures matter independent of the prevailing legal tradition in a country.

Policy conclusions can be drawn only on the basis of a normative model. Before opting in favor of judicial procedures that maximize economic growth, a discussion of desired goals is appropriate. Societies might be willing to forego some economic growth if the consequence of such is a lower probability that innocent suspects will be falsely convicted. This is a critical issue, but beyond the scope of this particular paper.

On a more mundane level, it is also necessary to consider that the optimal mix of procedural aspects is a function of a country's state of development. Countries with few highly-qualified legal professionals and where the majority of contracts are simple might need procedures that are different from those needed in a country where the average contract is much more complex and there are relatively more engaged in the legal profession.

Finally, it would be helpful to have more precise data. For example, the information provided by the U.S. State Department is of great help, but the "sometimes" category is coarse; better refinement would lead to better-quality results. 


\section{Appendix}

Table A1: Descriptive statistics of the 10 judicial procedure indicators from Hathaway, the seven criteria from Djankov et al., and the four legal origin indicators

\begin{tabular}{|c|c|c|c|c|}
\hline & Min. & Max. & Mean & Std. Dev. \\
\hline \multicolumn{5}{|l|}{ Procedural variables } \\
\hline Judiciary independent and impartial & -1.00 & 0 & -0.579 & 0.391 \\
\hline Right to counsel & -0.75 & 0 & -0.323 & 0.188 \\
\hline Right to present defense & -0.67 & 0 & -0.174 & 0.176 \\
\hline Presumption of innocence & -0.83 & 0 & -0.156 & 0.173 \\
\hline Right to appeal & -0.50 & 0 & -0.060 & 0.100 \\
\hline Timeliness & -1.00 & 0 & -0.438 & 0.299 \\
\hline No ex post facto laws & -0.17 & 0 & -0.004 & 0.020 \\
\hline Public trial & -0.42 & 0 & -0.061 & 0.100 \\
\hline Charges presented prior & -0.75 & 0 & 0.226 & 0.187 \\
\hline Right to interpreter & -0.25 & 0 & 0.010 & 0.045 \\
\hline \multicolumn{5}{|l|}{ Formalism in tenant case } \\
\hline Professionals vs. laymen & 0 & 1.00 & 0.625 & 0.247 \\
\hline Written vs. oral elements & 0.38 & 1.00 & 0.734 & 0.166 \\
\hline Legal justification & 0.72 & 1.00 & 0.725 & 0.292 \\
\hline Regulation of evidence & 0 & 1.00 & 0.371 & 0.177 \\
\hline Control of superior review & 0 & 1.00 & 0.742 & 0.265 \\
\hline Engagement formalities & 0 & 1.00 & 0.283 & 0.286 \\
\hline Independent procedural actions & 0 & 1.00 & 0.287 & 0.194 \\
\hline \multicolumn{5}{|l|}{ Formalism in check case } \\
\hline Professionals vs. laymen & 0 & 1.00 & 0.592 & 0.274 \\
\hline Written vs. oral elements & 0.38 & 1.00 & 0.739 & 0.174 \\
\hline Legal justification & 0 & 1.00 & 0.678 & 0.308 \\
\hline Regulation of evidence & 0 & 0.88 & 0.372 & 0.169 \\
\hline Control of superior review & 0 & 1.00 & 0.722 & 0.265 \\
\hline Engagement formalities & 0 & 1.00 & 0.258 & 0.278 \\
\hline Independent procedural actions & 0 & 1.00 & 0.239 & 0.192 \\
\hline \multicolumn{5}{|l|}{ Legal origin variables } \\
\hline Legal origin: Common law & 0 & 1.00 & 0.274 & 0.446 \\
\hline Legal origin: French & 0 & 1.00 & 0.415 & 0.493 \\
\hline Legal origin: German & 0 & 1.00 & 0.067 & 0.249 \\
\hline Legal origin: Scandinavian & 0 & 1.00 & 0.037 & 0.189 \\
\hline Legal origin: Socialist & 0 & 1.00 & 0.200 & 0.400 \\
\hline
\end{tabular}


Table A2: Correlation coefficients of judicial variables: Eviction of a tenant

\begin{tabular}{|c|c|c|c|c|c|c|c|c|}
\hline Eviction of a tenant: & Judiciary & $\begin{array}{l}\text { Right to } \\
\text { counsel }\end{array}$ & $\begin{array}{l}\text { Right to } \\
\text { defense }\end{array}$ & $\begin{array}{l}\text { Presumption } \\
\text { of innocence }\end{array}$ & $\begin{array}{l}\text { Right to } \\
\text { appeal }\end{array}$ & Timeliness & Public & $\begin{array}{l}\text { Charges } \\
\text { presented }\end{array}$ \\
\hline Professional vs. laymen & 0.13 & 0.14 & 0.12 & 0.02 & 0.01 & $0.28 *$ & 0.04 & -0.08 \\
\hline Written vs. oral elements & $0.35^{* *}$ & 0.19 & $0.22(*)$ & 0.14 & 0.08 & $0.29 *$ & -0.12 & -0.06 \\
\hline Legal justification & 0.06 & 0.01 & -0.11 & -0.17 & -0.01 & 0.18 & -0.15 & -0.07 \\
\hline Statutory regulation of evidence & $0.42 * *$ & $0.39 * *$ & 0.15 & 0.16 & 0.03 & $0.32 * *$ & 0.15 & $0.29 *$ \\
\hline Control over superior review & 0.09 & -0.08 & 0.01 & 0.15 & 0.03 & 0.13 & -0.19 & -0.06 \\
\hline Engagement formalities & $0.36^{* *}$ & 0.18 & 0.04 & -0.04 & 0.09 & $0.37 * *$ & -0.05 & -0.01 \\
\hline Independent procedural actions & $0.36^{* *}$ & $0.36 * *$ & $0.34 * *$ & $0.27^{*}$ & $0.29 *$ & $0.41 * *$ & $0.25^{*}$ & 0.18 \\
\hline
\end{tabular}

Notes: ${ }^{* *},{ }^{*}$, and $(*)$ indicate significance at the $1 \%, 5 \%$, and $10 \%$ level, respectively. 
Table A3: Correlation coefficients of judicial variables: Collection of a check

\begin{tabular}{|c|c|c|c|c|c|c|c|c|}
\hline Collection of a check: & Judiciary & $\begin{array}{l}\text { Right to } \\
\text { counsel }\end{array}$ & $\begin{array}{l}\text { Right to } \\
\text { defense }\end{array}$ & $\begin{array}{l}\text { Presumption } \\
\text { of innocence }\end{array}$ & $\begin{array}{l}\text { Right to } \\
\text { appeal }\end{array}$ & Timeliness & Public & $\begin{array}{l}\text { Charges } \\
\text { presented }\end{array}$ \\
\hline Professional vs. laymen & 0.16 & 0.14 & 0.12 & 0.06 & 0.14 & $0.26^{*}$ & -0.06 & -0.01 \\
\hline Written vs. oral elements & $0.29 *$ & $0.22(*)$ & $0.22(*)$ & -0.04 & 0.04 & $0.27 *$ & -0.06 & -0.09 \\
\hline Legal justification & 0.10 & 0.00 & -0.11 & -0.17 & 0.07 & $0.25^{*}$ & -0.14 & -0.14 \\
\hline Statutory regulation of evidence & $0.40 * *$ & $0.36 * *$ & 0.15 & 0.19 & 0.02 & $0.31 * *$ & 0.16 & $0.26^{* *}$ \\
\hline Control over superior review & 0.13 & -0.04 & 0.01 & 0.16 & -0.01 & 0.14 & -0.16 & -0.10 \\
\hline Engagement formalities & $0.37 * *$ & 0.18 & 0.04 & -0.03 & 0.08 & $0.36^{* *}$ & -0.04 & -0.05 \\
\hline Independent procedural actions & $0.45^{* *}$ & $0.38 * *$ & $0.34 * *$ & $0.32 * *$ & 0.20 & $0.47^{* *}$ & $0.23(*)$ & 0.12 \\
\hline
\end{tabular}

Notes: ${ }^{*},{ }^{*}$, and $(*)$ indicate significance at the $1 \%, 5 \%$, and $10 \%$ level, respectively. 
Table A4: Correlation coefficients of judicial variables: Legal Origins

\begin{tabular}{|c|c|c|c|c|c|c|c|c|}
\hline Legal origin: & Judiciary & $\begin{array}{l}\text { Right to } \\
\text { counsel }\end{array}$ & $\begin{array}{l}\text { Right to } \\
\text { defense }\end{array}$ & $\begin{array}{l}\text { Presumption } \\
\text { of innocence }\end{array}$ & $\begin{array}{l}\text { Right to } \\
\text { appeal }\end{array}$ & Timeliness & Public & $\begin{array}{l}\text { Charges } \\
\text { presented }\end{array}$ \\
\hline English & -0.19 & 0.16 & 0.05 & $0.27 *$ & 0.08 & -0.07 & -0.04 & $0.32 * *$ \\
\hline French & $0.37 * *$ & 0.10 & 0.04 & -0.12 & 0.07 & $0.43 * *$ & 0.09 & -0.04 \\
\hline German & -0.08 & -0.13 & 0.11 & 0.08 & -0.06 & $-0.26^{*}$ & 0.11 & -0.11 \\
\hline Scandinavian & $-0.31 *$ & $-0.30^{*}$ & $-0.27 *$ & $-0.24(*)$ & -0.15 & $-0.36 * *$ & -0.16 & $-0.27 * *$ \\
\hline Socialist & 0.03 & -0.05 & -0.01 & -0.15 & -0.09 & -0.10 & -0.10 & -0.17 \\
\hline
\end{tabular}

Notes: ${ }^{*}, *$, and $(*)$ indicate significance at the $1 \%, 5 \%$, and $10 \%$ level, respectively. 
Table A5: List of 67 included countries

\begin{tabular}{|c|c|c|c|}
\hline Argentina & Ecuador & Jamaica & Senegal \\
\hline Australia & Egypt & Japan & Singapore \\
\hline Austria & El Salvador & Jordan & South Africa \\
\hline Belgium & France & Malawi & Sri Lanka \\
\hline Benin & Germany & Malaysia & Sweden \\
\hline Botswana & Greece & Netherlands & Thailand \\
\hline Brazil & Guatemala & New Zealand & Tunisia \\
\hline Canada & Honduras & Norway & Turkey \\
\hline Chile & Hungary & Pakistan & Uganda \\
\hline Cyprus & Ireland & Philippines & Zambia \\
\hline Denmark & Israel & Poland & Zimbabwe \\
\hline Dominican Republic & Italy & Portugal & \\
\hline
\end{tabular}




\section{References}

Banks, A. (2004); Banks' Cross-National Time-Series Data Archive; distributed by Databanks International, Binghamton, NY.

Barro, R. (1997); Determinants of Economic Growth: A Cross-Country Empirical Study, Cambridge, MA: MIT Press.

Barro, R. and J.-W. Lee (2000); International Data on Educational Attainment: Updates and Implications, NBER Working Paper 7911, September.

Brutus in: Ketcham, R. (1986; ed.): The Anti-Federalist Papers and the Constitutional Convention Debates, 120-7.

de Haan, J. and J.-E. Sturm (2000); On the Relationship Between Economic Freedom and Economic Growth, European Journal of Political Economy 16: 215-241.

Djankov, S., R. La Porta, F. Lopez-de-Silanes, and A. Shleifer (2003); Courts: The Lex Mundi Project, Quarterly Journal of Economics 118: 453-517.

Durlauf, S. and M. Fafchamps (2005); Social Capital, in: Ph. Aghion and S. Durlauf (eds.): Handbook of Economic Growth 1B; North Holland, ch. 26.

Feld, L. and S. Voigt (2003); Economic Growth and Judicial Independence: Cross Country Evidence Using a New Set of Indicators, European Journal of Political Economy 19: 497-527.

Feld, L. and S. Voigt (2006); Making Judges Independent-Some Proposals Regarding the Judiciary. In: R. Congleton and B. Swedenborg (eds.): Democratic Constitutional Design and Public Policy-Analysis and Evidence, Cambridge: MIT Press, 251-88.

Freedom House (2002); The Annual Survey of Press Freedom; available at: http://www.freedomhouse.org/pfs2002/pfs2002.pdf.

Hathaway, O. (2002); Do Human Rights Treaties Make a Difference? Yale Law Journal 111: 1935-2042.

Hayo, B. and S. Voigt (2007); Explaining De Facto Judicial Independence, International Review of Law and Economics 27: 269-290.

Hendry, D. F. (1993); Econometrics: Alchemy or Science? Oxford: Blackwell.

Hendry, D. F. and H.-M. Krolzig (1999); Improving on "Data Mining Reconsidered" by K. D. Hoover and S. J. Perez, Econometrics Journal 2: 202-219.

Heston, A., R. Summers, and B. Aten (2006); Penn World Table Version 6.2, Center for International Comparisons of Production, Income and Prices at the University of Pennsylvania, September. 
Hoover, K. D. and S. J. Perez (1999); Data Mining Reconsidered: Encompassing and the General-to-Specific Approach to Specification Search, Econometrics Journal 2: 167191.

Jarque, C. M. and A. K. Bera (1987); A Test for Normality of Observations and Regression Residuals, International Statistical Review 55: 163-172.

La Porta, R., F. Lopez-de-Silanes, A. Shleifer, and R. Vishny (1999); The Quality of Government, Journal of Law, Economics, and Organization 15: 222-279.

Leamer, E. E. (1978); Specification Searches, New York: John Wiley.

Poe, S., N. Tate, and L. C. Keith (1999); Repression of the Human Right to Personal Integrity Revisited: A Global Cross-National Study Covering the Years 1976-1993, International Studies Quarterly 43: 291-313.

Ramsey, J. B. (1969); Tests for Specification Errors in Classical Linear Least Squares Regression Analysis, Journal of the Royal Statistical Society B 31: 350-371.

White, H. (1980); A Heteroskedastic-Consistent Covariance Matrix Estimator and a Direct Test for Heteroskedasticity, Econometrica 48: 817-838. 


\section{CESifo Working Paper Series}

for full list see www.cesifo-group.org/wp

(address: Poschingerstr. 5, 81679 Munich, Germany, office@cesifo.de)

2449 Jan Bouckaert, Hans Degryse and Thomas Provoost, Enhancing Market Power by Reducing Switching Costs, November 2008

2450 Frank Heinemann, Escaping from a Combination of Liquidity Trap and Credit Crunch, November 2008

2451 Dan Anderberg, Optimal Policy and the Risk Properties of Human Capital Reconsidered, November 2008

2452 Christian Keuschnigg and Evelyn Ribi, Outsourcing, Unemployment and Welfare Policy, November 2008

2453 Bernd Theilen, Market Competition and Lower Tier Incentives, November 2008

2454 Ondřej Schneider, Voting in the European Union - Central Europe's Lost Voice, November 2008

2455 Oliver Lorz and Gerald Willmann, Enlargement versus Deepening: The Trade-off Facing Economic Unions, November 2008

2456 Alfons J. Weichenrieder and Helen Windischbauer, Thin-Capitalization Rules and Company Responses, Experience from German Legislation, November 2008

2457 Andreas Knabe and Steffen Rätzel, Scarring or Scaring? The Psychological Impact of Past Unemployment and Future Unemployment Risk, November 2008

2458 John Whalley and Sean Walsh, Bringing the Copenhagen Global Climate Change Negotiations to Conclusion, November 2008

2459 Daniel Mejía, The War on Illegal Drugs in Producer and Consumer Countries: A Simple Analytical Framework, November 2008

2460 Carola Frydman, Learning from the Past: Trends in Executive Compensation over the Twentieth Century, November 2008

2461 Wolfgang Ochel, The Political Economy of Two-tier Reforms of Employment Protection in Europe, November 2008

2462 Peter Egger and Doina Maria Radulescu, The Influence of Labor Taxes on the Migration of Skilled Workers, November 2008

2463 Oliver Falck, Stephan Heblich and Stefan Kipar, The Extension of Clusters: Differencein-Differences Evidence from the Bavarian State-Wide Cluster Policy, November 2008 
2464 Lei Yang and Keith E. Maskus, Intellectual Property Rights, Technology Transfer and Exports in Developing Countries, November 2008

2465 Claudia M. Buch, The Great Risk Shift? Income Volatility in an International Perspective, November 2008

2466 Walter H. Fisher and Ben J. Heijdra, Growth and the Ageing Joneses, November 2008

2467 Louis Eeckhoudt, Harris Schlesinger and Ilia Tsetlin, Apportioning of Risks via Stochastic Dominance, November 2008

2468 Elin Halvorsen and Thor O. Thoresen, Parents' Desire to Make Equal Inter Vivos Transfers, November 2008

2469 Anna Montén and Marcel Thum, Ageing Municipalities, Gerontocracy and Fiscal Competition, November 2008

2470 Volker Meier and Matthias Wrede, Reducing the Excess Burden of Subsidizing the Stork: Joint Taxation, Individual Taxation, and Family Splitting, November 2008

2471 Gunther Schnabl and Christina Ziegler, Exchange Rate Regime and Wage Determination in Central and Eastern Europe, November 2008

2472 Kjell Erik Lommerud and Odd Rune Straume, Employment Protection versus Flexicurity: On Technology Adoption in Unionised Firms, November 2008

2473 Lukas Menkhoff, High-Frequency Analysis of Foreign Exchange Interventions: What do we learn?, November 2008

2474 Steven Poelhekke and Frederick van der Ploeg, Growth, Foreign Direct Investment and Urban Concentrations: Unbundling Spatial Lags, November 2008

2475 Helge Berger and Volker Nitsch, Gotcha! A Profile of Smuggling in International Trade, November 2008

2476 Robert Dur and Joeri Sol, Social Interaction, Co-Worker Altruism, and Incentives, November 2008

2477 Gaëtan Nicodème, Corporate Income Tax and Economic Distortions, November 2008

2478 Martin Jacob, Rainer Niemann and Martin Weiss, The Rich Demystified - A Reply to Bach, Corneo, and Steiner (2008), November 2008

2479 Scott Alan Carson, Demographic, Residential, and Socioeconomic Effects on the Distribution of $19^{\text {th }}$ Century African-American Stature, November 2008

2480 Burkhard Heer and Andreas Irmen, Population, Pensions, and Endogenous Economic Growth, November 2008 
2481 Thomas Aronsson and Erkki Koskela, Optimal Redistributive Taxation and Provision of Public Input Goods in an Economy with Outsourcing and Unemployment, December 2008

2482 Stanley L. Winer, George Tridimas and Walter Hettich, Social Welfare and Coercion in Public Finance, December 2008

2483 Bruno S. Frey and Benno Torgler, Politicians: Be Killed or Survive, December 2008

2484 Thiess Buettner, Nadine Riedel and Marco Runkel, Strategic Consolidation under Formula Apportionment, December 2008

2485 Irani Arraiz, David M. Drukker, Harry H. Kelejian and Ingmar R. Prucha, A Spatial Cliff-Ord-type Model with Heteroskedastic Innovations: Small and Large Sample Results, December 2008

2486 Oliver Falck, Michael Fritsch and Stephan Heblich, The Apple doesn't Fall far from the Tree: Location of Start-Ups Relative to Incumbents, December 2008

2487 Cary Deck and Harris Schlesinger, Exploring Higher-Order Risk Effects, December 2008

2488 Michael Kaganovich and Volker Meier, Social Security Systems, Human Capital, and Growth in a Small Open Economy, December 2008

2489 Mikael Elinder, Henrik Jordahl and Panu Poutvaara, Selfish and Prospective: Theory and Evidence of Pocketbook Voting, December 2008

2490 Maarten Bosker and Harry Garretsen, Economic Geography and Economic Development in Sub-Saharan Africa, December 2008

2491 Urs Fischbacher and Simon Gächter, Social Preferences, Beliefs, and the Dynamics of Free Riding in Public Good Experiments, December 2008

2492 Michael Hoel, Bush Meets Hotelling: Effects of Improved Renewable Energy Technology on Greenhouse Gas Emissions, December 2008

2493 Christian Bruns and Oliver Himmler, It's the Media, Stupid - How Media Activity Shapes Public Spending, December 2008

2494 Andreas Knabe and Ronnie Schöb, Minimum Wages and their Alternatives: A Critical Assessment, December 2008

2495 Sascha O. Becker, Peter H. Egger, Maximilian von Ehrlich and Robert Fenge, Going NUTS: The Effect of EU Structural Funds on Regional Performance, December 2008

2496 Robert Dur, Gift Exchange in the Workplace: Money or Attention?, December 2008

2497 Scott Alan Carson, Nineteenth Century Black and White US Statures: The Primary Sources of Vitamin D and their Relationship with Height, December 2008 
2498 Thomas Crossley and Mario Jametti, Pension Benefit Insurance and Pension Plan Portfolio Choice, December 2008

2499 Sebastian Hauptmeier, Ferdinand Mittermaier and Johannes Rincke Fiscal Competition over Taxes and Public Inputs: Theory and Evidence, December 2008

2500 Dirk Niepelt, Debt Maturity without Commitment, December 2008

2501 Andrew Clark, Andreas Knabe and Steffen Rätzel, Boon or Bane? Others' Unemployment, Well-being and Job Insecurity, December 2008

2502 Lukas Menkhoff, Rafael R. Rebitzky and Michael Schröder, Heterogeneity in Exchange Rate Expectations: Evidence on the Chartist-Fundamentalist Approach, December 2008

2503 Salvador Barrios, Harry Huizinga, Luc Laeven and Gaëtan Nicodème, International Taxation and Multinational Firm Location Decisions, December 2008

2504 Andreas Irmen, Cross-Country Income Differences and Technology Diffusion in a Competitive World, December 2008

2505 Wenan Fei, Claude Fluet and Harris Schlesinger, Uncertain Bequest Needs and LongTerm Insurance Contracts, December 2008

2506 Wido Geis, Silke Uebelmesser and Martin Werding, How do Migrants Choose their Destination Country? An Analysis of Institutional Determinants, December 2008

2507 Hiroyuki Kasahara and Katsumi Shimotsu, Sequential Estimation of Structural Models with a Fixed Point Constraint, December 2008

2508 Barbara Hofmann, Work Incentives? Ex Post Effects of Unemployment Insurance Sanctions - Evidence from West Germany, December 2008

2509 Louis Hotte and Stanley L. Winer, The Demands for Environmental Regulation and for Trade in the Presence of Private Mitigation, December 2008

2510 Konstantinos Angelopoulos, Jim Malley and Apostolis Philippopoulos, Welfare Implications of Public Education Spending Rules, December 2008

2511 Robert Orlowski and Regina T. Riphahn, The East German Wage Structure after Transition, December 2008

2512 Michel Beine, Frédéric Docquier and Maurice Schiff, International Migration, Transfers of Norms and Home Country Fertility, December 2008

2513 Dirk Schindler and Benjamin Weigert, Educational and Wage Risk: Social Insurance vs. Quality of Education, December 2008

2514 Bernd Hayo and Stefan Voigt, The Relevance of Judicial Procedure for Economic Growth, December 2008 